\title{
JOURNAL.RU
}

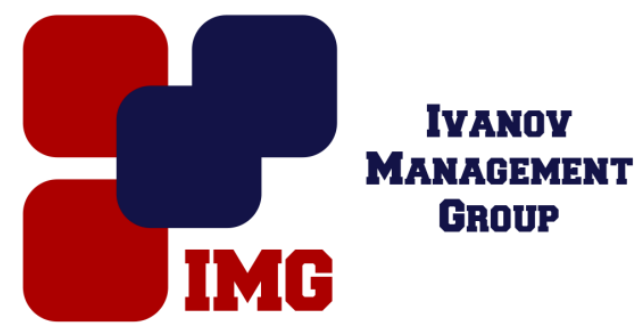

Вилитенко T.O. Академия ФСИН России Рязань, Россия

doi: $10.18411 / 1 \mathrm{j}-31-05-2017-46$

idsp 000001:1j-31-05-2017-46

\section{Дифференциация уголовной ответственности за хищение чужого имущества}

Дифференциация будет представлять собой своего рода разделения санкций в уголовном законодательстве от менее тяжких к более тяжким, все зависит от характера и вида совершенного хищения. Чем опаснее преступление, тем суровей наказание будет предусмотрено для виновного лица. Однако, не все так просто, автор выделяют следующую проблему:бросается в глаза несоответствие санкций, установленных законом за различные виды хищений, в результате чего УК допускает ситуации, когда простые грабеж (ст. 161 УК) и разбой (ст. 162 УК) при отягчающих обстоятельствах наказываются строже, чем аналогичные деяния, совершенные в отношении специального вида имущества.

Так, грабеж чужого имущества, совершенный в особо крупном размере (ч. 3 ст. 161 УК), наказывается лишением свободы от шести до двенадцати лет. В то же время открытое хищение предметов, имеющих особую ценность, независимо от размера стоимости похищенного подлежит наказанию по ч. 1 ст. 164 УК в виде лишения свободы от шести до десяти лет. Статья 221 УК об ответственности за хищение либо вымогательство ядерных материалов или радиоактивных веществ также не учитывает размер похищенного, и при отсутствии иных отягчающих обстоятельств характеризуемое деяние здесь наказывается лишением свободы на срок до пяти лет.

То же самое в полной мере касается и других видов хищения, а именно оружия (ст. 226 УК) и наркотиков (ст. 229). Правда, для всех них стоимость похищенного по смыслу закона не имеет столь важного значения. Особенно это касается хищения наркотических средств и психотропных веществ, где более 
важно учитывать количество самих этих субстанций. Тем не менее вызывает удивление сам факт такого различного понимания разработчиками УК общественной опасности всех обозначенных преступлений.

Далее, если за хищение обычного имущества, совершенное путем разбоя, с незаконным проникновением в жилище, помещение либо иное хранилище в соответствии с ч. 3 ст. 162 УК законом предусмотрено наказание в виде лишения свободы на срок от семи до двенадцати лет, то за это же деяние, совершенное в отношении культурных ценностей, которое подпадает под действие лишь ч. 1 ст. 164 УК, получается всего от шести до десяти лет.

Еще более существенная разница в пределах санкций наблюдается между разбоем (п. п. «б», «в» ч. 4 ст. 162 УК), совершенным в особо крупном размере, сопряженным с причинением тяжкого вреда здоровью потерпевшего, и разбойным нападением в целях хищения культурных ценностей при тех же обстоятельствах (ч. 1 ст. 164 УК).

Как представляется, при дифференциации уголовной ответственности за хищение того или иного имущества нельзя игнорировать то обстоятельство, что способ совершения этого преступления значительно влияет на характер и степень его общественной опасности, поскольку помимо отношений собственности рассматриваемое деяние может причинять вред еще и другим объектам (здоровью человека, а также его личным правам и свободам).

Пытаясь разрешить данную ситуацию, отдельные авторы в подобных случаях предлагают квалифицировать деяния по совокупности преступлений. Однако совершенно очевидно, что это не выход из положения, поскольку он противоречит принципу справедливости, в соответствии с которым никто не может быть привлечен к уголовной ответственности дважды за одно и то же деяние.

Среди них особенно выделяется непримиримая коллизия норм об ответственности за различные виды хищения, в случаях, когда предмет преступления сочетает в себе одновременно несколько юридически значимых черт. Такая коллизия, например, возникает между нормами, закрепленными ст. 164 УК и ст. 226 УК, применительно к ситуации, когда похищенное имущество, с одной стороны, является оружием, а с другой - представляет особую историческую или иную культурную ценность. Скажем, когда злоумышленники крадут из музея или у частного коллекционера фитильный мультук XVII в. или в качестве предмета хищения выступает, например, пистолет Сталина. 
Очевидно, что по совокупности преступлений уголовный закон в данной ситуации применять нельзя, поскольку речь идет о единичном деянии. Но какую тогда следует выбрать норму? Оба состава - и содержащийся в ст. 164 УК, и закрепленный ст. 226 УК - являются специальными по отношению к краже, предусмотренной ст. 158 УК, или к грабежу (ст. 161 УК) и т.д., и потому по отношению друг к другу они равнозначны.

На практике в вопросе о том, каким свойствам похищенного имущества в данном случае отдавать предпочтение, специалисты чаще всего склоняются в сторону оружия. Причем эксперты-криминалисты рассматривают априори как оружие даже старинные капсюльные и кремневые пистолеты, несмотря на то что выстрелить из них, по существу, может только специалист-оружиевед.

Но и это еще не все. Ученые уже давно говорят о том, что специальные виды хищения, предусмотренные ст. ст. 221, 226 и 229 УК, имеют иную социально-правовую сущность и не вписываются в понятие хищения, закрепленное в примечании 1 к ст. 158 УК. По справедливому замечанию многих авторов, эти преступления часто лишены корыстной мотивации (а именно в таком ключе их часто квалифицируют и на практике), для них в силу особенностей предмета посягательства не столь важны признаки безвозмездности деяния и причинения имущественного ущерба. При этом в качестве альтернативы обозначения данных деяний ученые предлагают использовать термин «похищение».

Статьями Особенной части УК РФ не предусмотрено в качестве обстоятельства, влекущего более строгое наказание, совершение двух или более краж, грабежей и разбоев. Согласно статье 17 УК РФ при совокупности преступлений лицо несет уголовную ответственность за каждое совершенное преступление по соответствующей статье или части статьи УК РФ, наказание назначается отдельно за каждое совершенное преступление. При этом окончательное наказание в соответствии с частями второй и третьей статьи 69 УК РФ не может превышать более чем наполовину максимальный срок или размер наказания, предусмотренного за наиболее тяжкое из совершенных преступлений.

Автором была рассмотрена основа дифференциации уголовной ответственности за хищения, которая выражается в разделении целого на части, а именно разделение уголовной ответственности от менее тяжких последствий, к более тяжким последствиям. Такой подход позволяет наиболее просто назначить наказание виновному лицу за совершенное деяние. Чем опаснее преступления, 
тем и характер ответственности будет тяжелее. Также на характер уголовной ответственности будет влиять наличие специального субъекта, особенностью объекта посягательства, проще говоря, характер и степень самого деяния. Между тем, были рассмотрены вопросы квалификации, которые наиболее часто возникают в практической деятельности. Из этого следует необходимость тщательного изучения самого деяния, эго элементы и стороны, чтобы правильно определить квалификацию.

1. Севрюков А.П. Криминологическая и уголовно-правовая характеристика грабежей и разбоев, совершенных с незаконным проникновением в жилище: Дис... канд. юрид. наук. М.: ВНИИ МВД РФ, 2008.

2. Севрюков А.П. Хищение имущества: криминологические и уголовно-правовые аспекты. М., 2014.

3. Теплова Д.О., Корыстная цель и мотив как признаки хищения, 2015.

4. Уголовное право России / под редакцией В.Н. Кудрявцева А.В. Наумова. Т. 2, Особенная часть. 2016. 